Оригинални научни рад

УДК 811.163.41'342-053.4/.5(497.11Врање)

$811.163 .41 ' 282.2$

Примљен: 17. фебруара 2021.

Прихваћен: 6. март 2021.

Драгана В. Станковић ${ }^{1}$

https://doi.org/10.46630/phm.13.2021.43

Универзитет у Нишу

Педагошки факултет у Врању

Катедра за језике и књижевност

\title{
СОЦИОЛИНГВИСТИЧКИ ПРИСТУП НЕКИМ ФОНЕТСКИМ КАРАКТЕРИСТИКАМА ГОВОРА МЛАДИХ ВРАҢАНАЦА
}

\begin{abstract}
Спроведено социолингвистичко истраживање усмерено је на испитивање следећих фонетских карактеристика у говору младих Врањанаца: полугласника, доследног екавизма у одричним облицима глагола јесам, губљења сугласника $x$ и рефлекса -(j)a од финалног $\pi$ у наставку радног глаголског придева глаголског придева мушког рода. Наведене језичке варијабле посматрају се у односу на оне друштвене варијабле које су релевантне за језичко понашање деце: узраст, пол, образовање родитеља, место становања, похађање вртића / школе. Имајући у виду интензивно варирање дијалекатских и стандарднојезичких облика под утицајем стандардног језика, својствено говору младих, циљ нашег истраживања је да се опишу одређене фонетске карактеристике и прикажу њихове варијације, а затим да се утврди њихова заступљеност у говору младих Врањанаца и условљеност нејезичким факторима. Анализиране фонетске карактеристике показују варијабилност и висок степен изложености промени, замени стандарднојезичким формама. Највећу стабилност показује губљење сугласника $x$, а најмању екавски облици несам, неси..., на основу чега се може говорити о даљем правцу развоја фонетског система врањског говора. Нејезички чиниоци, у извесној мери, утичу на употребу фонетских дијалектизама, осим узраста - са узрастом се не смањује фреквенција дијалекатских облика.
\end{abstract}

Кључне речи: фонетски дијалектизми, врањски говор, говор младих, социолингвистички приступ

\section{1. Увод}

Врањски говор припада најјужнијем делу призренско-јужно-

1 draganast@pfvr.ni.ac.rs

2 У раду су представљени резултати једног дела истраживања, спроведеног за потребе израде докторске дисертације под називом Говор вранске деще предшколског и школског узраста - соииолингвистички приступ, одбрањене на Филолошком факултету у Београду 2. 7. 2018. године. 
моравског дијалекта. Извесним специфичностима у гласовном систему, граматичкој структури и веома богатој и сликовитој лексици овај говор заузима посебно место међу призренско-јужноморавским говорима. Међутим, под утицајем образовања, средстава јавне комуникације, те свеопште интелектуализације говора, али и стида и дискриминације говорника овог краја, многе дијалекатске црте врањског говара се повлаче или су мање фреквентне. Тенденцију приближавања овог говора стандардном језику наглашавају сви његови истраживачи (BARJAKTAREVIĆ 1965; PAVLOVIĆ 1966; MARINKOVIĆ 1987, 1994; TRAJKOVIĆ, MIHAJLOVIĆ 2020). Промене су свакако највидљивије у говору најмлађих Врањанаца.

Говор деце представља једну некристалисану мешавину, један систем у превирању, у коме су видљиви наговештаји, импулси језичких промена. Такође, деца показују склоност ка диглосивном понашању, промени језичког израза у зависности од различитих нејезичких чинилаца (више о томе у TRAJKOVIĆ 2018a; TRAJKOVIĆ, MIHAJLOVIĆ 2020). Jeзичке варијације које притом настају на релацији дијалекат -стандардни језик значајан су показатељ (не)стабилности дијалекатских црта. Опис варијација језичких појава и њихове условљеност низом друштвених, нејезичких чинилаца предмет су социолингвистички оријентисаних истраживања.

Социолингвистичка истраживања стављају у фокус језик као систем којим се служе говорници с одговарајућим друштвеним обележјима, као што су: пол, узраст, порекло, образовање, национална и верска припадност, корелацију између језичких и друштвених чинилаца, те диференцирање у зависности од друштвених параметара. Употреба језика варира у зависности од узраста, пола, степена образовања, друштвеног статуса, а такође и у зависности од саговорника, од говорне ситуације и друштвеног контекста, што заправо значи да појединац користи низ варијација које су углавном свесно контролисане и могу се користити онде где ситуација то захтева. На један начин говоре припадници млађих, а на други припадници старијих генерација, на један начин они с вишим степеном образовања, на други с нижим, на један начин се говори у формалној ситуацији, на други у неформалној и сл. Отуда и разни варијетети, генерацијски, образовни, полни.

Доследнију примену методологије социолингвистичких истраживања на нашем простору налазимо тек на крају 20. и на почетку 21. века у радовима Д. Јовића (1979), Љ. Рајића (1980), Т. Магнера (1983), С. Станковића (1997), П. Л. Томе (1998), Ж. Бошњаковића и И. Књижара (2012), Т. Трајковић (2013, 2016b, 2017, 2018a, 2018b), Д. Станковић (2017, $2018,2020)$ и зборницима Говор Нової Саgа. Свеска 1: Фонейске особине (BOŠNJAKOVIĆ 2009a) и Говор Нової Саgа. Свеска 2: Морфосинйаксичке, 
лексичке и йраїматиччке особине (VASIĆ, ŠTRBAC 2011), који се могу сматрати приручником социјалне дијалектологије.

У судару дијалекта и стандардног језика у дијалекатском систему настају промене које захватају језичке нивое у различитој мери. Досадашња социолингвистичка истраживања су показала да су морфолошке и синтаксичке особине подложније променама него фонолошке (JUTRONIĆ-TIHOMIROVIĆ 1988-1989; PAJИЋ 2009: 42; BOŠNJAKOVIĆ, KNJIŽAR 2012). Како је говор младих индикатор промена, желели смо да утврдимо у којој мери се мења фонетски систем у говору младих Врањанаца.

Фонетски систем врањског говора разликује се, у извесној мери, од система стандардног српског језика. На плану фонетике издвајају се следеће дијалекатске карактеристике: полугласник (gaнbc), рефлекс -на- < -нж- код глагола 3. Белићеве врсте (йagнаја), доследан екавизам у одричним облицима глагола јесам (неје, несмо), специфични рефлекси вокалног $\pi$ (лу, льу, ли: слуза, жльчка, gлибок), рефлекс -(j)a од финалног $\pi$ у радном глаголском придеву мушког рода (азguсаја, ойugнаја), финал-

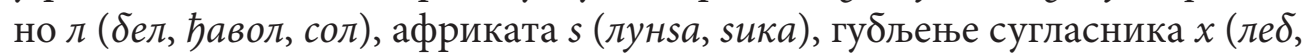
gоояи, оума).

Приликом истраживања фонетског система одабрали смо четири фонетске карактеристике типичне за врањски говор, које сваки носилац овог говорног типа поседује у свом говору - полугласник, доследан екавизам у одричним облицима глагола јесам, губљење сугласника $x$ и рефлекс -(j)a од финалног л у наставку радног глаголског придева мушког рода. Истраживање је спроведено према принципима актуелних социолингвистичких истраживања.

\section{2. Методологија истраживања}

Имајући у виду интензивно варирање дијалекатских и стандарднојезичких облика под утицајем стандардног језика својствено говору младих, циљ нашег истраживања је да се опишу одређене фонетске карактеристике говора младих Врањанаца и прикажу њихове варијације, а затим да се утврди у којој мери су присутни дијалекатски облици и колико су они условљени нејезичким факторима.

Ради остварења наведеног циља, постављена су три истраживачка задатка:

1. описати све варијације анализираних фонетских карактеристика говора младих Врањанаца;

2. утврдити фреквентност употребе дијалекатских облика;

3. утврдити условљеност употребе дијалекатских облика следећим нејезичким чиниоцима: узрастом, полом, образовањем родитеља, 
местом становања (центар / периферија града), похађањем вртића / шко$\pi \mathrm{e}^{3}$.

Посматрањем варијација и утврђивањем фреквентности дијалекатских облика добићемо увид у њихову заступљеност и (не)стабилност, док ћемо укрштањем језичких и нејезичких (друштвених) варијабли утврдити које друштвене варијабле у највећој мери утичу на промене.

Анализиран је говор 40 испитаника узраста од 5 до 14 година, различитог пола, места становања (центар / периферија града), образовања родитеља, похађања вртића / школе. Испитаници су изједначени по једној друштвеној варијабли - пореклу: сва деца су рођена и живе у Врању, као и њихови родитељи. Према узрасту, испитаници су разврстани у три групе - деца предшколског узраста (16 испитаника), школског узраста од првог до четвртог разреда (12 испитаника) и школског узраста од петог до осмог разреда (12 испитаника). У оквиру предшколског узраста једну групу чине деца која иду у вртић (12 испитаника), а другу деца која не иду у вртић (4 испитаника). Девојчица је 20, а исто толико и дечака. Према месту становања једну групу чине деца која живе у центру града (20 испитаника), а другу групу деца која живе на периферији (20 испитаника). Према образовању родитеља једну групу чине деца чија су оба родитеља с високим (вишим) образовањем (12 испитаника), другу деца чији је један родитељ с високим (вишим) образовањем а други са средњим (13 испитаника) и трећу деца чија су оба родитеља са средњим образовањем (15 испитаника).

Грађа је прикупљена техником интервјуа отвореног типа (неструктуираног интервјуа), који је испитивач водио с испитаницима. Разговор с испитаницима вођен је на дијалекту о различитим темама блиским испитаницима с циљем да се они опусте и на тај начин забележи њихов свакодневни, спонтани говор.

Разговор је сниман диктафоном и транскрибован. Снимљени разговори трају од једног до два сата са сваким испитаником, тј. два школска часа с децом школског узраста. Тако је добијена грађа од око 70 сати аудио-снимака. У транскрибованом материјалу издвојене су и анализиране одговарајуће фонетске карактеристике.

Најпре је дата квалитативна анализа - опис одговарајућих фонетских карактеристика и њихових варијација, с освртом на досадашња дијалектолошка проучавања врањског (BELIĆ 1999; BARJAKTAREVIĆ 1965) и суседних говора - пчињског (JURIŠIĆ 2009, 2014), прешевског (TRAJKOVIĆ 2016а) и пољаничког говора (STEVANOVIĆ 1969).

Потом следи квантитативна анализа - израчунавање индекса

3 Социолингвистича истраживања су показала да су наведени нејезички чиниоци релевантни за језичко понашање деце (RAJIĆ 2009: 39). 
фреквенције (ИФ) којим се утврђује фреквентност дијалекатских облика анализираних фонетских карактеристика. ИФ се добија тако што се број забележених дијалекатских облика најпре подели са збиром дијалекатских и стандарднојезичких облика, а затим помножи са $100^{4}$ :

$$
\text { ИФ }=\frac{\text { дијалекатски облици }}{\text { дијалекатски и стандарднојезички облици }}
$$

На основу добијене вредности индекса фреквенције закључује се о употреби дијалекатског облика - виши ИФ указује на учесталију употребу дијалекатског облика. Добијени резултати тумаче се методом дескриптивне анализе и приказују помоћу табела.

\section{3. Фонетске карактеристике - квалитативна анализа}

\section{1. Полугласник}

У врањском говору, као и у свим говорима призренско-тимочке говорне зоне (РECO 1989: 43; IVIĆ 2001: 147; OKUKA 2008: 233), полугласник се чува на месту старог и секундарног полугласника, у акцентованим и неакцентованим слоговима, у корену речи и наставцима. Међутим, дијалектолошка истраживања врањског и суседних говора указују на врло интензиван процес вокализације полугласника (STEVANOVIĆ 1969: 403; BARJAKTAREVIĆ 1976: 322-323; OKUKA 2008: 223; JURIŠIĆ 2009: 52-53; TRAJKOVIĆ 2016a: 323).

У анализираном говору врањске деце полугласник је присутан, али у ограниченом броју речи ${ }^{5}$ :

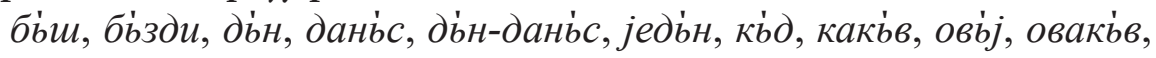

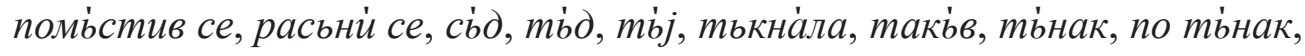

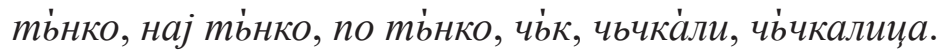

Већи број речи с полугласником истовремено се изговара и с пу-

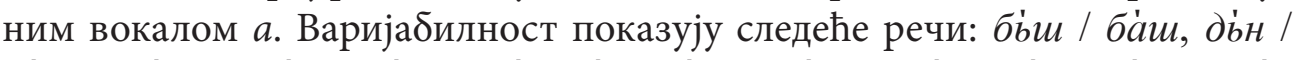

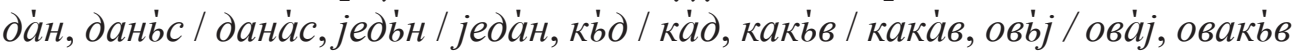

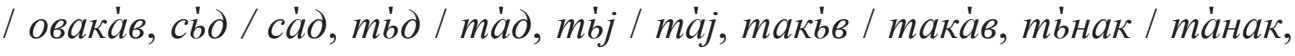

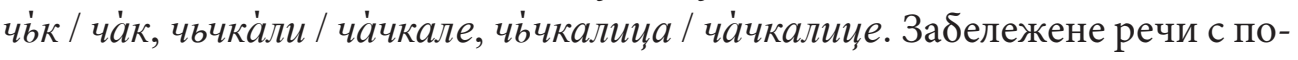
лугласником варијабилност не показују у изведеницама и сложеницама, које су махом стандарднојезички облици: не́кад, нијкад, није́дан / ниједа́н,

4 Овај образац у својим социолингвистичким истраживањима користе Д. Јутронић и Ж. Бошњаковић.

5 А. Белић (1999: 87-89) врло је детаљно описао порекло и гласовну вредност полугласника, користећи диграме за различите нијансе у изговору. Ми те нијансе нисмо бележили, а у обележавању полугласника определили смо се за један знак $b$, који се најчешће користи у литератури. 
једа்нпут / једанпу̀m, ниједа́нпут / ниједанпу̇т, отка́д, не́какав, нйкакав, поне́кад, имендан, ро́ђендан, су́традан, заса́d, доса́d, одса́d, дота́д. Тако је и у стандарднојезичком облику компаратива и суперлатива та́ње, на́jтағе, као и облику најта́нкије.

У већем броју речи у којима је употребљен, полугласник је у на-

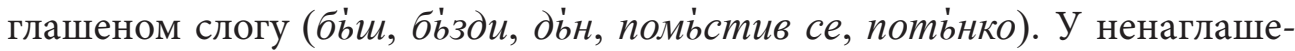
ном слогу је само у трима речима: расьни се, тькна́ла и чьчка́ли. У речима

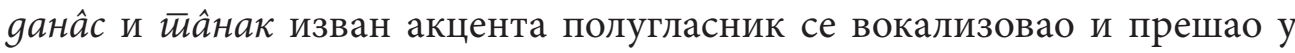
пуни вокал $a$, док се онај под акцентом чува. Још је А. Белић (1999: 106) установио да полугласник у неакцентованом слогу чешће и лакше прелази у пуни вокал. До таквог закључка долази и Д. Барјактаревић (1976: 323) анализирајући полугласник у јужноморавској говорној зони и М. Јовановић $(2003: 296,299)$ анализирајући полугласник на ширем ареалу јужнословенског говорног простора, у говорима Црне Горе, Србије и Македоније. С тим у вези, стандарднојезичко место акцента доприноси вокализацији полугласника: да́нас, је́дан, ка́кав, оввај, ова́кав, та́кав, ча́чкале.

У великом броју речи полугласник је вокализован, независно од позиције, акцента и порекла:

ве́тар, во́сак, да́ске, до́бар, доручак, за́р, је́сам, ка́кво / какво́, ка́ко / како́, не́како, ни่како, кобаја́ги, кобаја́шки, ко́наи, коно́паи, ла́жу, ла́же, ла́жов, ла́к, ла́ка, ла́ке, ла́ко, лако்ћу, ле́баи, Ле́сковаи, ло́наи, мале́иак, ма́ске, ма́скембал, маскира́ли, маскирано, ма́сне, ма́ч, ма́чујемо се, моззак, мо́кар, мо́мак, не́кад, нинкад, ниссам / не́сам, но́кат, ова́ко / овако́, ова́кве / овакве́, ован, оннај / она́ј, онакав / онака́в, оннако / онако́, орао, осам, осалде́сет, оса̇мнес, папри́ка, па́с, пе́сак, Пе́тар, пе́так, пола́ко, пра́вила / правйла, пу́пак, руччак, са, сас, сабирање, савија́о, сакријем, сакрио, сакриंјев, саку̀пила / сакупйла, сам, са̀н, сања́ла, са́ъам, сачува́ла, сашйо, сва́какве, се́дам, се́дамнес (m), ситан, сла́дак, сре́ћан, стра́на, странииу, та́ко / тако́, та́кве / такве́, тама́н, та́мне, зата́мњена, те́сан, толииак, час, шіапнем

Облици радног придева глагола прве врсте су без полугласника, а акценат је померен за један слог напред: до́mја, иза́mja, úmja, на́mja,

6 Дијалектолози наведене речи бележе с полугласником, уп.: зьр, изльжа̇ме га, йзльга,

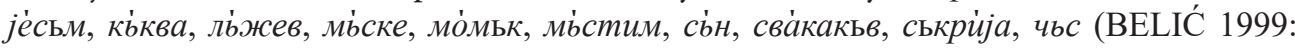

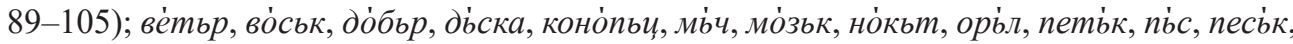
сьчува́, ськупй, ськриммо се, ты́мно (BARJAKTAREVIĆ 1965: 35); сь, сьс (STEVANOVIĆ 1969: 403); льж (BARJAKTAREVIĆ 1976: 323); льњже (MARINKOVIĆ 1987: 55); біјјzи,

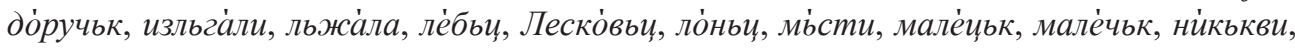

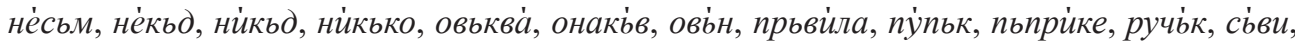
сла̇тьк, сьшијјy, сьшијје, сьшијев, тькве́, толиччк, те́сьн, тамїн, шьпна́ ми (JURIŠIĆ

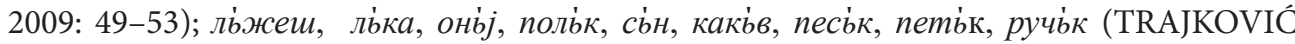
2016a: 320-321). 
omímја (уп. у пољаничком говору: дошіј и ищíj (STEVANOVIĆ 1969: 404); у врањском: на́шьja (MARINKOVIĆ 1987: 53); у пчињском: дошіjјa,

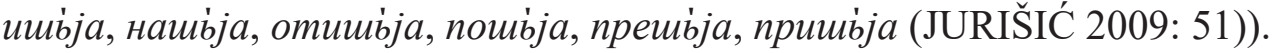

У неким речима налазимо вокале $о$ и $y$ на месту где дијалекто-

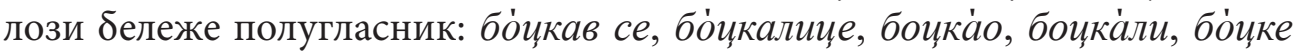
(уп. бь́ину, убьикав га (JURIŠIĆ 2009: 50)), куде́, откуде́ (уп. кьде́ (BELIĆ

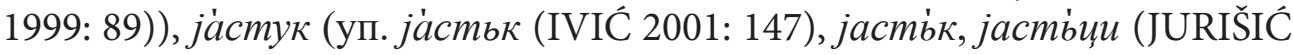
2009: 50)), комшилу̀к / комшиилук (уп. комшиль́к (JURIŠIĆ 2009: 51)). На другој страни, у Врању и суседним говорима потврђени су следећи облици с вокалима $e$, o и у на месту полугласника: Петро́вден, тега́j, поприंка, ова́ков, собор о осум, осумна́јс, се́дом, седомна́јс (BELIĆ 1999: 107-108); ӧге, юојјен, Велигден, ложйиа, се́дом, о́сом, мо́гла, име́ја, о́zењ (JURIŠIĆ 2009: 53); Велигден, дек, ложице, собо́р, о́сом (TRAJKOVIĆ 2016а: 325). Овакви облици нису својствени говору млађих.

\section{2. Екавизам у одричним облицима глагола јесам}

Сви досадашњи истраживачи врањског и суседних говора констатовали су доследну екавску замену старог гласа јат у одричном облику помоћног глагола јесам у презенту (BARJAKTAREVIĆ 1965: 35; STEVANOVIĆ 1969: 403; JURIŠIĆ 2009: 54; TRAJKOVIĆ 2016а: 330). Ова појава својствена је и косовско-ресавским говорима ${ }^{7}$.

У говору наших испитаника овај екавизам је присутан, али није доследан - смењују се дијалекатски (а) и стандарднојезички облици (б), при чему су стандарднојезички облици фреквентнији. Наводимо део грађе:

1.л.јд.

(a) не́сам се растужи́ла; то́j не́сам чу̀ја ни́кад у живо́т;

(б) ниссам би́о у вр́тић; нйсам их ви́део у ли́це; у тра́мвај нйсам се возйо; ја̀ го́дину да́на нйсам трени́рала;

2.л.јд.

(а) не́си јӧш на ре́ду;

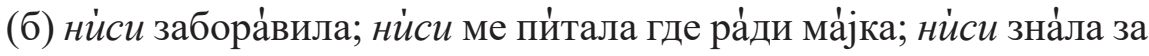
њy்; ка̇да нйси до́бар; ка́жу - ти่ нйси ти́;

3.л.јд.

(a) не́jе дуга́чка то́лко; о̀н не́је погина́ја; не́је јёдноставно;

(б) нйje носи́ла јӧш га́ће на мо̀ре; ни јёдан ни дру́ги нйје из Вра̇ња; за девојјчице нйје стро́г; го́ре у пе́т са́ти нйје хла́дно; 1.л.мн.

(a) не́смо бйли; не́смо оставйли све́ске; мй не́смо и́шли;

7 Видети: ALEKSIĆ, VUKOMANOVIĆ 1966: 294; JOVIĆ 1968: 52-53; RADIĆ 1997: 5859. 
(б) ду́го нйсмо би́ли у њи́ву; ме́сец да̇на нйсмо прича́ле; ову́ го́дину нйсмо (китили јелку); код ове́ на́ставнице нйсмо ста́ли;

2.л.мн.

(б) а с Ву́ка нйсте; нйсте зна́ли; нйсте ле́по спа́вали; 3.л.мн.

(a) не́су ни скака̇ли ке́нгури; не́су такви́ про́зори; не́су ста̇ри;

(б) у цр́тани ниссу а́гресивни; за црте́жи ми нйсу ре́кли; сви́ што нйсу до́бри; нйсу у и́сто оделе́ње; нйсу ни ме́сец да̇на про́шли.

Док су сва лица овог глагола изражена дијалекатским и стандарднојезичким обликом, облик другог лица множине употребљен је само у стандарднојезичком облику. У питању је званична форма персирања, која је условила употребу само стандарднојезичког облика.

Екавизам у основи негираног глагола јесам у неким косовскоресавским говорима изостаје у 3. л. јд. испред сонанта $j$ (в. GRKOVIĆ 1968: 122; RADIĆ 1997: 58, 2000: 387). У ексцерпираној грађи нашли су се и екавски и икавски облици 3. л. јд.

Посебну пажњу привлаче облици 3. л. јд. с одричном речцом не уместо није: не ме је боле́ло; та́та не ме је возйо; та́та не ме је пуштйо; не се ни мрда́ја; не ме стра́; та́та не ми извадијја; не се пријавијја; не ми се йшло. Овај тип негације, у коме је одрична речца одвојена енклитичком заменицом од глагола ${ }^{8}$, А. Белић (1999: 403) бележи у најјужнијем делу јужноморавског говора и објашњава га македонским утицајем ${ }^{9}$. П. Ивић ову појаву назива „проклитизацијом енклитике“ $(2009: 163)^{10}$. У анализираном говору она се јавља само у негираним исказима.

\section{3. Губљење сугласника $x$}

Сугласник $x$ је данас изразито нестабилан глас у свим говорима српског језика ${ }^{11}$. Описујући говоре призренско-тимочке говорне зоне, А. Белић наглашава да је сугласник $x$ у овим говорима ишчезао у свим по-

8 УП.: „По правилу енклитика, поготову ако припада глаголској сфери, долази после негираног комплекса, а никад после 'не““ (SIMIĆ 2011: 11).

9 А. Белић наводи следеће примере из Врања: како да не́ се бојев па́mе; како не́ те је срам; не́ ти тре́ба; не́ га је убіја; да не́ се ка́жеш дек смо аџијје; да не́ гу вйди (1999: 403). Б. Видоески у македонским говорима наводи појаву одвајања партикуле не од глагола заменичком енклитиком: не ми збори; не се љути на мене (1998: 97).

10 Р. Младеновић (2013: 406-408) ову појаву у говорима јужне Метохије и јужног Косова објашњава утицајем типа линеаризације из контактног несловенског језика, али и из суседних македонских говора. С. Милорадовић (2015: 79-80) бележи „тежњу ка проклитизацији заменичких и глаголских енклитика“ у неким периферним српским говорима - у српским говорима Баната, северне и јужне Метохије и јужног Косова.

11 О судбини овог сугласника на балканском језичком подручју в. РЕСО 1995. 
ложајима у речи. Ипак, у неким речима, у финалној позицији, он бележи врло слабо артикулисано, редуковано $x$. Такво $x$ налази најчешће у турским речима, али и на почетку речи испред самогласника где није било

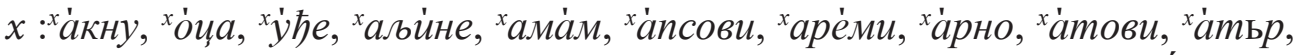

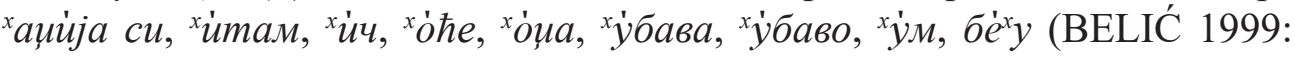
172-173). У неким речима Белић бележи к уместо $x$ : за Крйста бо́га, $\dot{a}$ - $^{-}$ тикрис, Мика́јле, па́зуку, па́зуке, приंкод (Исто: 174).

И дијалектолози после Белића указују на нестабилност сугласника $x$ и његову замену гласовима $8, j, \kappa$ у говору Врања и околине (BARJAKTAREVIĆ 1965: 41; STEVANOVIĆ 1969: 407; TOMIĆ 2007: 198; JURIŠIĆ 2009: 88-89; TRAJKOVIĆ 2016a: 370-371). Ипак, неки од њих констатују да сугласник $x$ није у потпуности нестао, да се може чути

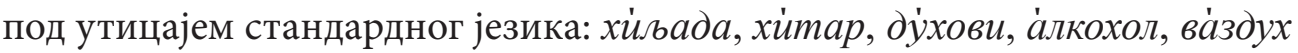
(STEVANOVIĆ 1969: 407); Ха́н, хле́баи, хра́на, њи்хов (TOMIĆ 2007: 198); хра́на, хаљйне, бронхитис, маха́ла, сахра́нев, сахранйла, ва́здух (JURIŠIĆ 2009: 88); маха́ла, пре́хлада, са́храна, ха́ртију, хальйна (TRAJKOVIĆ 2016a: 370).

Наше истраживање показује да се у говору млађе врањске популације сугласник $x$ полако стабилизује. Готово у истом $\delta$ роју речи се јавља и губи. Такође, нема забележених примера супституције гласовима j и $\kappa$, а забележен је само један дијалекатски облик са супституентом в у медијалној позицији - гревот $a^{12}$, поред стандарднојезичких облика $\delta y в а$, мува, уво, кувам.

Сугласник $x$ изостаје у следећим речима, у иницијалној, медијалној и финалној позицији:

àj, ájде, а́јмо, а́ло, йъада, йъаде, ла́дан, ла́дно, ле́б, ле́ба, ле́баи, оћу, оћеш, о̇ћ, о̇ћете, те́о, те́ла, те́ло, те́ли;

греотта, две́иљадито, ма́ала, ма́алу;

стра́, о̀дма, jà (не) бй.

Супституција сугласничке групе $x в$ сугласником $\oint$ односно сонантом в на морфолошкој граници потврђена је у следећим речима:

фа́ла, фа́та, фа́ти, фа́ли се;

дофа́тим, пофа́ти, пофа́лим, уфа́ти, уфатй, уфатиंла, уфатйли, уфа́тимо, ува́тим, (не) ува́ти.

12 Дијалектолози у врањском крају бележе следеће облике са супституентима $j, \kappa, 8$ : закте́вав, Кри́ста, Крйстијани, Микайл, па́зуке, паро́кија (BARJAKTAREVIĆ 1965: 41); дре́је, меју̀нка, кра́на, паро́кија, пле́к, сна́ва, не бе́ву, грево́та (STEVANOVIĆ 1969: 407);

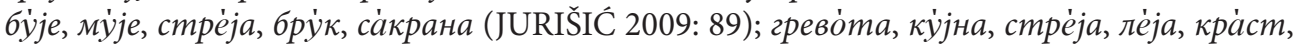
кúтно, закте́ва, пле́кови (TRAJKOVIĆ 2016а: 371). А. Белић објашњава: „Представници дијалекта који није знао за $x$ уопште, чујући тај звук у говору својих сународника,

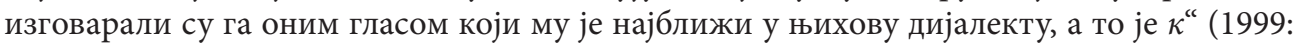
174). 
Сугласник $x$ ниједном није употребљен у облику првог лица једнине аориста:

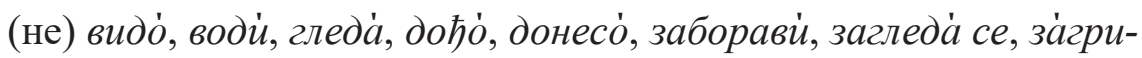
за, збуни се, згазй, иззади, изнервира́ се, исеко́ се, йспадо, наставй, обја-

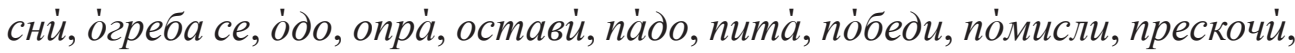

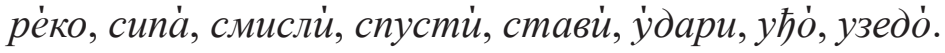

$\mathrm{У}$ речима с другим дијалекатским цртама, губљење сугласника $x$ је стабилно: ӧћев, те́ја, те́ше, фаћа́о, фа́лив се, почна́, расьни́ се, спушти́ $c e$. Само у једном примеру овог типа употребљен је сугласник $x: x \dot{\partial} а a$.

Сугласник $x$ варијабилност показује у следећим речима:

ха́jде / а́jде, хйљада / йъада, хла́дно / ла́дно, хле́б / ле́б, хле́ба / ле́ба, хо̇ћу, хӧћеш... / оћу, оћеш..., хте́о, хте́ла.. / те́о, те́ла.., хва́ла / фа́ла, хва́та / фа́та, хва́тао / фаћа́о; две́хиљадито / две́иљадито, дохва́тим / дофа́тим, похва́лим / пофа́лим, ухва́ти / уфа́ти, ухва́тио / ухва-

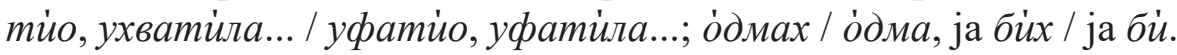

Већина речи са сугласником $x$ су страног порекла:

ха́кује, ха́ла, ха́ло, ха́мер, ха́ос, ха́убу, хела́нке, хела́нкице, хелико́птер, хело̀ (сок), хе́мија, хе́миске (оловке), херој, химна, хиру́ргију, хистеріме, хо́би, хо́кеј / хоке́ј, хокуса, холл, хор , хорор, хот-дог, хоте́л;

ӓлкохол, архив, архитекту̀ра, аутомеха́ничар, бронхитис, ја́хта, механизам, механнччар, пеххар, психички, психолога, психологгја, те́хнику, те́хнички, те́хничко, техноло́гија, те́хнолошки, у̇нихоп , ша̇ховске, uáxmy;

стйx, ménux, ша̇x.

Сугласник $x$ је стабилан и у властитим именицама, у свим позицијама у речи:

Робин Ху̀да, Халкидйки, Ха́на, Ха́нчанка, Хањио́ти, Хари Потер, Хе́nи, Беверли Хйлс, Хйтлер, Хо́бит, Хола́ндију, Хо́ливуд, Хрйстијана, Христов;

Бошко Бу̀ха, Мйнхен, Миха̇јло, Миха̇љко, Ӧхрид, Пефкохо́ри, Стра́хиға, Те́хна, Те́хничка школа ;

Се́вдах (назив ресторана).

Сугласник $x$ бележимо и у наставцима именичке и заменичкопридевске промене:

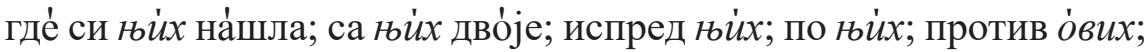
доно́сим са свйх стра́на; због ли่чних ра́злога; на́пасти од мо́jux сеста́ра; пу̀цамо против невидљьиви Нѐмаца; не узймам од не́познатих љу̀ди; против дру́сих горми́та; образова́ње о́драслих; на сва́ку акаде́мију дра́мских

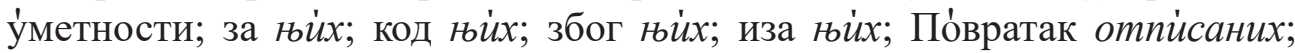
де́лење ра́щионалних бро́јева; Да̇н за́љубљених.

У наведеним примерима $x$ иде уз преузете називе из стандардног 
језика или стандарднојезичке падежне конструкције. Тако је и са стандарднојезичким обликом енклитичке заменице $u x$.

Сугласник $x$ чује се и у узвицима аха и ђиха.

На нестабилност и несигурност у употреби сугласника $x$ указују забележене речи с овим сугласником уместо сугласника $\kappa$ у медијалној позицији: пре́хјуче, хелихо́птер, хелихоптери. У једној речи $x$ се налази у иницијалној позицији: хле́д.

Ексцерпирана грађа потврђује став Д. Јовића „да се фонема /x/ спорије враћа у оним речима у којима је некада елиминисана у народном говору (хлеб / леб, махао / маао, хлаgно / лаgно) и да је готово потпуно стабилна у речима примљеним у новије време (Хавана, хауба, хаубица, храм, хор, мохер, кох)“ (1979: 245). До таквог запажања дошао је и Ж. Бошњаковић: „фонема $x$ у речима у којима је раније елиминисана данас се теже васпоставља. Знатно је стабилнија у лексемама примљеним у новије време“ (2009b: 271).

\section{4. Рефлекс -(j)a од финалног л у радном глаголском придеву мушког рода}

Наставак -(j)a (рефлекс финалног -л) у мушком роду једнине радног глаголског придева је једна од особина по којој се призренско-јужноморавски дијалекат разликује од осталих дијалеката призренско-тимочке говорне зоне ${ }^{13}$. Овај наставак дијалектолози бележе и у говору Врања и околине: да́ja, удрйjа, каза́jа, стихја, за́шја, зате́кја, порасна́jа, бидна́jа (BELIĆ 1999: 384-391); вика́jа, бра́jа, гледа́jа, чека́ја,

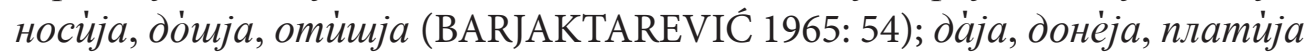
(MARINKOVIĆ 1987: 53); мо́гja, насмеја́ja, menája, виде́ja, до́шja, úmja, узе́jа, помја, на́шjа (JURIŠIĆ 2009: 222); писува́ја, намава́jа, прода́jа, рабomúja (TRAJKOVIĆ 2016a: 501).

Спорадично, забележени су и други облици: виде́а ли си (384), чине́а, умре́а, је́а, одне́а (388); изле́гал (107), умеа́л (325) (BELIĆ 1999); домша, отйша (BARJAKTAREVIĆ 1965: 54).

Када су у питању глаголи прве врсте с инфинитивом на - $ћ u$, дијалектолози у говору врањског краја бележе, поред наставка -ja, и наставке -ьја, -аја, -еја": мога́jа, доше́ja (BELIĆ 1999: 388-389); доша́jа,

13 П. Ивић наглашава: „ј у -аја свакако је аналошким путем пренесено из облика где се развило гласовно иза $e$ или $u$. У једнини м. р. радног глаголског придева ја је механизовано и раширено миграцијама по свим говорима јужноморавског дијалекта“ (2001: 148).

14 А. Белић објашњава: „У осталом, искључива употреба партиципа на ја показује да је наставка л брзо нестало из ових дијалеката; а наставци aja, bja, еја и сл. у партиципима, који су некад имали стари наставак $b л$, показују да се он заиста још неко време 
omиmája (BARJAKTAREVIĆ 1965: 54); отиша̇j, дошíu, проша̇j, доша́j,

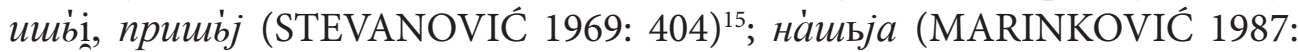
53); ишіј a, прешіја, отишіјја, нашшіја и спорадично - отише́ја, проше́ја (JURIŠIĆ 2009: 223-224) ${ }^{16}$. Тако је и у говорима северне Македоније: дошја и дошьја, дошаја, рекја и рекаја (VIDOESKI 1998: 67, 98).

У говору врањске деце предшколског и школског узраста врло је интензивно колебање дијалекатског (а) и стандарднојезичког облика (ס) радног глаголског придева мушког рода. Наводимо део грађе:

а) біјја, виде́ја, гледа́jа, добі́jа, заљубйја се, игра́jа, има́ја, купија, љубависа́ја се, мрда́jа, нагазијја, остави́ја, падна́ја, плака́ја, разуме́ја, са-

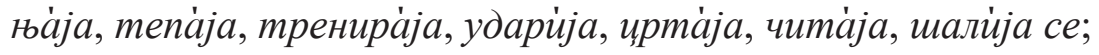

б) бйо, држы́о, живео, има́о, је́о, купа́о се, напи́сао, оживео, пьу́нуо, повре́дио, погину́о, позва́о, по́јео, ра́дио, скува́о, сру́шио, телепорттовао, уве́нуо, узе́о, хте́о, иртао.

У једном примеру бележимо наставак - $a$ : поје́a.

Већи је број примера с наставком -о у форми потенцијала:

воллео би / воле́о би, исповраћа́о би се, мора́о би, направйо би, одушевйо би се, прелете́о би, радйо би, не би садйо, сме́о би, хте́о би / те́о би, тре́бао би / треба́о би, у்био би, ударйо би, че́као би, шутира́о би.

На стабилност наставка -о указују примери у којима су неке дијалекатске особине глагола задржане, док је дијалекатски наставак -ја замењен стандарднојезичким: гурна́о, пипна́, погина́о, седна́о, скина́о, те́о, фаћа́o, yфатйо. Међу њим је и један лексички дијалектизам: липиао.

На другој страни, финална вокалска група која настаје по преласку -л у о често се сажима, под утицајем разговорног језика.

Код глагола прве врсте с инфинитивом на -ћи нема ниједног забележеног примера с несажетом групом:

до́шо, диго, иза́шо, изву̀ко, исе́ко, и́шо, ле́го, могго ${ }^{17}$, навйко се,

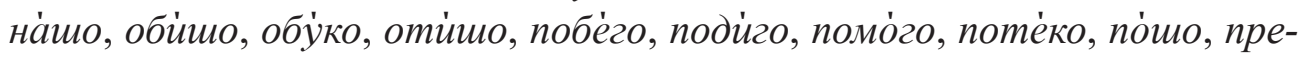
сви́ко, пре́шо, приву́ко, про́шо, пу่ко, ре́ко, се́ко, сишо, стиго, те́ко, ту́ко, $\dot{y} u о$.

употребљавао напоредо са новим облицима са ја, док се између њих није извршила контаминација“ (1999: 390).

15 Стевановић (1969: 404) наглашава да се све чешће у пољаничком говору, чак и код старијих људи, чује наставак -о у радном глаголском придеву под утицајем стандардног језика.

16 У пчињском говору овај тип глагола има двојаке облике - облике у којима се полугласник изгубио (gómja, на́mja, umjá) и облике у којима се полугласник под акцентом чува (gошіja, нашіja, ишijja) (JURIŠIĆ 2009: 223-224).

17 Радни придев глагола моћи употребљен је само у облику мого. Нема потврда за облик могаја који наводе А. Белић (1999: 388) и М. Јуришић (2009: 222). 
Сажимање групе -ао забележили смо и код глагола: покиंсо, поpáco, та́ко, тре́со.

Група -ео је углавном несажета (виде́о, во́лео, до́нео, живео, оживео, појео, узе́о), само су два забележена примера у којима је дошло до сажимања: вйдо и $\dot{z} о$.

\section{4. Фонетске карактеристике - квантитативна анализа}

Анализиране фонетске карактеристике су у говору деце заступљене у различитој мери. Израчунавањем индекса фреквенције дијалекатских форми долазимо до закључка о њиховој заступљености у свакодневном говору наших испитаника. У табели 1 дат је ИФ дијалекатских облика сваке фонетске карактеристике појединачно.

Табела 1. Индекс фреквенције gијалекайских облика
\begin{tabular}{|l|c|}
\hline \multicolumn{1}{|c|}{ Језичке варијабле } & ИФ \\
\hline Полугласник & 7,66 \\
\hline Облици несам,неси... & 5,27 \\
\hline Губљење сугласника $x$ & 44,43 \\
\hline $\begin{array}{l}\text { Рефлекс -ја<-л } \\
\text { у радном гл. придеву } \\
\text { м.р. }\end{array}$ \\
\hline
\end{tabular}

Статистички подаци указују на низак ИФ фонетских дијалектизама, на основу чега се може говорити о интензивнијим променама у фонетском језичком систему и знатном приближавању језичком стандарду. Најнижи ИФ има екавски рефлекс одричног облика помоћног глагола јесам у презенту (ИФ 5,27), што би значило да се овај фонетски дијалектизам најлакше мења. Потом следе рефлекс -ja<-л у радном гл. придеву м.р. (ИФ 7,02) и полугласник $(И Ф ~ 7,66)$. Знатно виши ИФ има губљење сугласника $x$ (ИФ 44,33), што говори о његовој релативној стабилности. Изостављање гласа $x$ је подржано стањем у разговорној варијанти српског језика, одакле се, такође, често губи.

Промене које захватају фонетски ниво могу се објаснити у складу са принципом истакнутости и стигматизованости - у контакту са стандардним језиком прво се губе оне дијалекатске црте за које говорник сматра да су друштвено истакнуте ${ }^{18}$. У прилог томе иде размишљање Н. Богдановића: „У сусрету са светом чији је језик ближи књижевном стандарду дијалекатски говорник настоји да елиминише из свог говора ону

18 Овим принципом служила се Д. Јутронић (2010) при описивању сплитског говора и Ж. Бошњаковић и И. Књижар (2012) у описивању говора Буњеваца Бајмока и Таванкута. 
црту по којој се највише и препознаје“ (2009: 15-16).

Дакле, с аспекта принципа стигматизованости, губљење сугласника $x$ није истакнута, друштвено стигматизована особина, па је због тога учестало у говору врањске деце. На другој страни, екавски рефлекс одричног облика помоћног глагола јесам у презенту говорници осећају као друштвено истакнутијом, маркантнијом дијалекатском цртом, зато је у свом говору замењују стандарднојезичким обликом.

Када је у питању условљеност језичких варијација нејезичким чиниоцима, израчунавањем ИФ фонетских дијалектизама у говору сваке групе испитаника у односу на узраст, пол, образовање родитеља, место становања, (не)похађање вртића и похађање вртића / школе долазимо до закључка које нејезичке варијабле у највећој мери утичу на промене. У табели 2 дат је ИФ дијалекатских облика сваке фонетске карактеристике у односу на одређене нејезичке чиниоце.

Табела 2. Индекс фреквениије gијалекайских облика у оgносу на нејезичке чиниоче

\begin{tabular}{|c|c|c|c|c|}
\hline \multirow[b]{2}{*}{$\begin{array}{l}\text { Нејезичке } \\
\text { варијабле }\end{array}$} & \multicolumn{4}{|c|}{ Језичке варијабле - ИФ } \\
\hline & Полугласник & $\begin{array}{c}\text { Облик } \\
\text { несам,неси... }\end{array}$ & $\begin{array}{c}\text { Губљење } \\
\text { сугласника } \\
\text { x }\end{array}$ & $\begin{array}{c}\text { Рефлекс } \\
\text {-ја<л у } \\
\text { радном гл. } \\
\text { придеву } \\
\text { м.р. }\end{array}$ \\
\hline \multicolumn{5}{|l|}{ Узраст } \\
\hline предшколски & 7,15 & 3,18 & 49,59 & 8,86 \\
\hline школски 4-1 & 5,52 & 4,02 & 36,94 & 3,13 \\
\hline школски 8-5 & 10,17 & 9,22 & 44,56 & 8,51 \\
\hline \multicolumn{5}{|l|}{ Пол } \\
\hline мушки & 8,19 & 5,69 & 45,69 & 6,23 \\
\hline женски & 7,13 & 4,86 & 43,19 & 9,44 \\
\hline \multicolumn{5}{|l|}{$\begin{array}{r}\text { Образов. } \\
\text { родит. }\end{array}$} \\
\hline високо & 3,03 & 0 & 27,44 & 1,61 \\
\hline $\begin{array}{l}\text { високо, } \\
\text { средње }\end{array}$ & 7,79 & 3,36 & 52,24 & 4,73 \\
\hline средње & 11,2 & 12,30 & 52,95 & 13,98 \\
\hline \multicolumn{5}{|l|}{ Место станов. } \\
\hline центар & 5,52 & 3,66 & 46,91 & 4,51 \\
\hline периферија & 9,62 & 7,10 & 40,76 & 10,21 \\
\hline
\end{tabular}


Драгана В. Станковић

\begin{tabular}{|r|c|c|c|c|}
\hline Вртић & & & & \\
\hline иде у вртић & 5,14 & 1,91 & 44,85 & 5,54 \\
\hline не иде у вртић & 17,41 & 7,69 & 64,57 & 25,75 \\
\hline Вртић/школа & & & & \\
\hline иде у вртић & 5,14 & 1,91 & 44,85 & 5,54 \\
\hline иде у школу & 8,05 & 6,66 & 40,59 & 5,79 \\
\hline
\end{tabular}

Статистички подаци показују различиту заступљеност фонетских дијалектизама у односу на узраст, пол, образовање родитеља, место становања и (не)похађање вртића / школе у анализираном говору.

Узраст као нејезичка варијабла не утиче доследно на заступљеност фонетских дијалектизама; с узрастом се не смањује употреба дијалекатских облика. Полугласник, губљење сугласника $x$ и $-j a<\pi$ у радном глаголском придеву м.р. заступљенији су у говору деце најниже и највише узрасне групе, без већих разлика у фреквенцији. Једино се фреквенција облика несам, неси... доследно повећава са узрастом. Овакав резултат може се објаснити јачим деловањем школе и ауторитета на ученике млађих разреда, док су ученици старијих разреда опуштенији и мање подложни утицају школе и одраслих. На другој страни, деца предшколског узраста уче и понашају се по моделу у свакој конкретној ситуацији. С тим у вези могуће је да је разговор на дијалекту наметнуо већи број дијалекатских облика.

Девојчице у мањој мери користе фонетске дијалектизме него дечаци. Ипак, разлика у употреби дијалекатских облика са становишта пола је мала. Супротно очекивањима, наставак - $(j) a<\pi$ у м. p. радног глаголског придева има виши ИФ код девојчица.

Образовање родитеља значајно утиче на употребу свих анализираних фонетских дијалектизама - ИФ дијалекатских облика се са степеном образовања родитеља смањује, тако да је разлика међу образовним групама значајна. Од овога одступа губљење сугласника $x$ - његова фреквентност је готово уједначена у говору испитаника друге и треће образовне групе.

Разлика у фреквенцији фонетских дијалектизама видљива је и са становишта места становања - дијалекатски облици свих анализираних фонетских карактеристика су заступљенији у говору испитаника са периферије него из центра града. Разлика између ове две групе је најмања када је у питањи фреквенција губљења сугласника $x$.

(Не)похађање вртића има значајан утицај на употребу фонетских дијалектизама у говору деце предшколског узраста - дијалекатска форма свих анализираних фонетских црта фреквентнија је у говору 
предшколске деце која не иду у вртић.

Анализа утицаја двеју образовних институција на употребу дијалекатских облика, вртића и школе, показује да школа не доприноси смањењу фреквенције фонетских дијалектизама у односу на вртић, иако у тој институцији има експлицитног утицаја на говор деце у виду организоване наставе граматике српског језика. Полугласник и екавски облици несам, неси... заступљенији су у говору деце која иду у школу, док је разлика у фреквенцији губљења сугласника $x$ и употребе рефлекса $-j a<\pi$ у радном гл. придеву м.р. незнатна.

\section{5. Закључак}

У истраживању фонетског система говора младих Врањанаца пратили смо следеће језичке варијабле, својствене врањском говору: полугласник, доследан екавизам у одричним облицима глагола јесам, губљење сугласника $x$ и рефлекс -(j)a од финалног л у наставку радног глаголског придева мушког рода. Наведене језичке варијабле посматране су у односу на друштвене варијабле које су релевантне за језичко понашање деце: узраст, пол, образовање родитеља, место становања, похађање вртића / школе. Спроведена анализа ексцерпиране грађе упућује на неколико закључака.

5.1. Анализиране фонетске карактеристике показују варијабилност - јављају се у дијалекатској и стандарднојезичкој форми у различитим категоријама речи. Полугласник се јавља у ограниченом броју речи, углавном под акцентом. Варијабилност не показује у изведеницама и сложеницама које долазе из стандардног језика (некаg, нијеgан, никакав, poђенgaн, gocag, најйане). Екавски и икавски облици негираног глагола јесам у презенту смењују се у свим лицима осим у 2. л. множине, у ком је званична форма персирања условила употребу само стандарднојезичког облика. Поновном успостављању сугласника $x$ доприносе речи страног порекла и властите именице, али се и даље теже успоставља у речима у којима је првобитно био елиминисан. Такође, стабилан је у наставцима именичке и заменичко-придевске промене и у узвицима. Интензивно је варирање наставака -ја и -о у м .р. јд. радног гл. придева, као и сажимање финалних група под утицајем разговорног језика (ищо, нашо, йрешо, йокисо, йресо).

5.2. Дијалекатске форме показују нестабилност - у већој мери су изложене промени, замени стандарднојезичким формама. Према фреквентности употребе, успостављена је следећа хијерархија фонетских дијалектизама:

1. екавски рефлекс одричног облика помоћног глагола јесам у 
презенту (ИФ 5,27),

2. рефлекс -ja<-л у радном гл. придеву м.р. (ИФ 7,02)

3. полугласник $(И Ф 7,66)$,

4. гуठљење сугласника $x$ (ИФ 44,33).

У складу са принципом истакнутости и стигматизованости, екавски рефлекс одричног облика помоћног глагола јесам у презенту је друштвено најистакнутија, дијалекатски маркатнија црта и због тога се она у судару са стандардним језиком прва мења. На другој страни, највећу стабилност показује губљење сугласника $x$, црта својствена и другим дијалектима, те као таква није истакнута и стигматизована. Хијерархија дијалекатских форми указује на правац даљег развоја фонетског система врањског говора - „склоност говорника да у одговарајућим ситуацијама мења одређене елементе из свог дијалекта заправо је путоказ кретања те категорије у будућности - најизложенији елемент ће се најпре изгубити из дијалекта“" (TRAJKOVIĆ, MIHAJLOVIĆ 2020: 96).

5.3. Фреквенција дијалекатских форми у извесној мери условљена је нејезичким, друштвеним варијаблама. Узраст је једина нејезичка варијабла која не утиче на фонетске карактеристике говора врањске деце - с узрастом се не смањује употреба дијалекатских форми (осим код облика несам, неси...). Највећи утицај на анализиране црте има образовање родитеља, а није занемарљив ни утицај места становања и похађања вртића. Разлике у фркевентности фонетских дијалектизама у говору дечака и девојчица су врло мале. Утицај школе је велик у периоду од првог до четвртог разреда, док се у периоду од петог до осмог разреда знатно смањује. У поређењу с вртићем, школа нема већи утицај на анализиране црте.

Фреквентност неких фонетских дијалектизама није условљена језичким чиниоцима. На губљење сугласника $x$ нема утицаја високо образовање једног родитеља ни место становања. Школа не потискује употребу полугласника и екавског рефлекса јата (облике несам, неси...). На употребу наставка -(j)a у м. р. јд. радног гл. придева не утиче пол и школа.

\section{Цитирана литература}

ALEKSIĆ, VUKOMANOVIĆ 1966: ALEKSIĆ, Radomir i Slavko VUKOMANOVIĆ. „Osnovne osobine aleksandrovačkog i bruskog govora“. Anali Filološkog fakulteta, VI (1966): str. 291-319. [orig.] АЛЕКСИЋ, Радомир и Славко ВУКОМАНОВИЋ. „Основне особине александровачког и бруског говора“. Анали Филолошког факултета, VI (1966): стр. 291-319.

BARJAKTAREVIĆ 1965: BARJAKTAREVIĆ, Danilo. „Fonetske i morfološke osobine vranjskog govora“. Vranjski glasnik, II (1965): cтp. 33-58. [orig.] 
БАРЈАКТАРЕВИЋ, Данило. „Фонетске и морфолошке особине врањског говора“. Врањски гласник, II (1965): стр. 33-58.

BARJAKTAREVIĆ 1976: BARJAKTAREVIĆ, Danilo. „Južnomoravska govorna zona u svetlu Belićeva ispitivanja i danas“. U: M. Stevanović (ur.), Zbornik radova o Aleksandru Beliću. Beograd: Srpska akademija nauka i umetnosti / Naučno delo, 1976, str. 321-332. [orig.] БАРЈАКТАРЕВИЋ, Данило. „Јужноморавска говорна зона у светлу Белићева испитивања и данас“. У: М. Стевановић (ур.), Зборник радова о Александру Белићу. Београд: Српска академија наука и уметности / Научно дело, 1976, стр. 321-332.

BELIĆ 1999: BELIĆ, Aleksandar. Dijalekti istočne i južne Srbije. Beograd: Zavod za udžbenike i nastavna sredstva, 1999. [orig.] БЕЛИЋ, Александар. Дијалекти источне и јужне Србије. Београд: Завод за уџбенике и наставна средства, 1999.

BOGDANOVIĆ 2009: BOGDANOVIĆ, Nedeljko. O leskovačkom govoru. Prilozi poznavanju srpskih narodnih govora 1. Leskovac: Leskovački kulturni centar, 2009. [orig.] БОГДАНОВИЋ, Недељко. О лесковачком говору. Прилози познавању српских народних говора 1. Лесковац: Лесковачки културни центар, 2009.

BOŠNJAKOVIĆ 2009a: BOŠNJAKOVIĆ, Žarko (ur.). Govor Novog Sada. Sveska 1: Fonetske osobine. Novi Sad: Filozofski fakultet, Odsek za srpski jezik i lingvistiku, 2009. [orig.] БОШЊАКОВИЋ, Жарко (ур.). Говор Новог Сада. Свеска 1: Фонетске особине. Нови Сад: Филозофски факултет, Одсек за српски језик и лингвистику, 2009.

BOŠNJAKOVIĆ 2009b: BOŠNJAKOVIĆ, Žarko. (2009b). „Fonema /h/ u govoru Novog Sada“. U: Ž. Bošnjaković (ur.), Govor Novog Sada. Sveska 1: Fonetske osobine. Novi Sad: Filozofski fakultet, Odsek za srpski jezik i lingvistiku, 2009, str. 268-286. [orig.] БОШЊАКОВИЋ, Жарко. „Фонема /x/ у говору Новог Сада“. У: Ж. Бошњаковић (ур.), Говор Новог Сада. Свеска 1: Фонетске особине. Нови Сад: Филозофски факултет, Одсек за српски језик и лингвистику, 2009, стр. 268-286.

BOŠNJAKOVIĆ, KNJIŽAR 2012: BOŠNJAKOVIĆ, Žarko i Ivan KNJIŽAR. „Sociolingvistički pristup nekim morfofonološkim promenama u govoru Bunjevaca Bajmoka i Tavankuta“. Srpski jezik, XVII (2012): str. 503-521. [orig.] БОШЊАКОВИЋ, Жарко и Иван КЊИЖАР. „Социолингвистички приступ неким морфофонолошким променама у говору Буњеваца Бајмока и Таванкута“. Српски језик, XVII (2012): стр. 503-521.

VASIĆ, ŠTRBAC 2011: VASIĆ, Vera i Gordana ŠTRBAC (ur.). Govor Novog Sada. Sveska 2: Morfosintaksičke, leksičke i pragmatičke osobine. Novi Sad: Filozofski fakultet, Odsek za srpski jezik i lingvistiku, 2011. [orig.] ВАСИЋ, Вера и Гордана ШТРБАЦ (ур.). Говор Новог Сада. Свеска 2: Морфосинтаксичке, лексичке и прагматичке особине. Нови Сад: Филозофски факултет, Одсек за српски језик и лингвистику, 2011.

VIDOESKI 1998: VIDOESKI, Božo. Dijalektite na makedonskiot jazik. Knj. I. Skopje: MANU, 1998. [orig.] ВИДОЕСКИ, Божо. Дијалектите на македонскиот јазик. Књ. І. Скопје: МАНУ, 1998. 
GRKOVIĆ 1968: GRKOVIĆ, Irena. „Neke osobine govora sela Lukova“. Prilozi proučavanju jezika, IV (1968): str. 123-131. [orig.] ГРКОВИЋ, Ирена. „Неке особине говора села Лукова“. Прилози проучавању језика, књ. IV (1968): стр. 123-131.

IVIĆ 2001: IVIĆ, Pavle. Dijalektologija srpskohrvatskog jezika. Celokupna dela Pavla Ivića, tom II. Priredio D. Petrović. Sremski Karlovci, Novi Sad: Izdavačka knjižarnica Zorana Stojanovića, 2001. [orig.] ИВИЋ, Павле. Дијалектологија српскохрватског језика. Целокупна дела Павла Ивића, том II. Приредио Д. Петровић. Сремски Карловци, Нови Сад: Издавачка књижарница Зорана Стојановића, 2001.

IVIĆ 2009: IVIĆ, Pavle. Srpski dijalekti i njihova klasifikacija. Priredio S. Remetić. Sremski Karlovci, Novi Sad: Izdavačka knjižarnica Zorana Stojanovića, 2009. [orig.] ИВИЋ, Павле. Српски дијалекти и њихова класификација. Приредио С. Реметић. Сремски Карловци, Нови Сад: Издавачка књижарница Зорана Стојановића, 2009.

JOVANOVIĆ 2003: JOVANOVIĆ, Miodrag. „Sudbina nekadašnjih poluglasnika u jakom položaju u govorima Crne Gore, Srbije i Makedonije“. Srpski jezik, VIII/1-2 (2003): str. 291-301. [orig.] ЈОВАНОВИЋ, Миодраг. „Судбина некадашњих полугласника у јаком положају у говорима Црне Горе, Србије и Македоније“. Српски језик, VIII/1-2 (2003): стр. 291-301.

JOVIĆ 1968: JOVIĆ, Dušan. „Trstenički govor“. Srpski dijalektološki zbornik, XVII (1968): str. 1-240. [orig.] ЈОВИЋ, Душан. „Трстенички говор“. Српски дијалектолошки зборник, XVII (1968): стр. 1-240.

JOVIĆ 1979: JOVIĆ, Dušan. „Sociolingvistički faktori jezičkih promena u župskom govoru“. Književnost i jezik, XXVI/2-3 (1979): str. 243-251. [orig.] JОВИЋ, Душан. „Социолингвистички фактори језичких промена у жупском говору“. Књижевност и језик, XXVI/2-3 (1979): стр. 243-251.

JURIŠIĆ 2009: JURIŠIĆ, Marina. Govor Gornje Pčinje: glasovi i oblici. Beograd: Institut za srpski jezik SANU, 2009. [orig.] ЈУРИШИЋ, Марина. Говор Горње Пчиње: гласови и облици. Београд: Институт за српски језик САНУ, 2009.

JURIŠIĆ 2014: JURIŠIĆ, Marina. „Sintaksa padeža Gornje Pčinje“. Srpski dijalektološki zbornik, LXI (2014): str. 373-533. [orig.] ЈУРИШИЋ, Марина. „Синтакса падежа Горње Пчиње“. Српски дијалектолошки зборник, LXI (2014): стр. 373-533.

JUTRONIĆ 2010: JUTRONIĆ, Dunja. Spliski govor - od vapora do trajekta. Split: Naklada Bošković, 2010.

MAGNER 1983: MAGNER, Thomas F. „Gradski dijalekti u Jugoslaviji“. Argumenti, 1-2 (1983): str. 187-195

MARINKOVIĆ 1987: MARINKOVIĆ, Javorka. „Osnovna obeležja govora Vranja i okoline“. Zbornik radova, V (1987): str. 53-55. [orig.] МАРИНКОВИЋ, Јаворка. „Основна обележја говора Врања и околине“. Зборник радова, V (1987): стр. 53-55.

MARINKOVIĆ 1994: MARINKOVIĆ, Javorka. „Generacijska diferencijacija kao osnov dijalekatskih razlika u govorima Vranjskog Pomoravlja“. U: Govori 
prizrensko-timočke oblasti $i$ susednih dijalekata. Niš: Filozofski fakultet u Nišu - Institut za srpski jezik SANU Beograd - Centar za naučna istraživanja SANU i Univerziteta u Nišu, 1994, str. 225-230. [orig.] МАРИНКОВИЋ, Јаворка. „Генерацијска диференцијација као основ дијалекатских разлика у говорима Врањског Поморавља“. У: Говори призренско-тимочке области и суседних дијалеката. Ниш: Филозофски факултет у Нишу - Институт за српски језик САНУ Београд - Центар за научна истраживања САНУ и Универзитета у Нишу, 1994, стр. 225-230.

MILORADOVIĆ 2015: MILORADOVIĆ, Sofija. „Srpski periferni govori - međujezički uticaji i balkanistički procesi“. Gwary Dziś, VII (2015): str. 71-82. [orig.] МИЛОРАДОВИЋ, Софија. „Српски периферни говори - међујезички утицаји и балканистички процеси“. Gwary Dziś, VII (2015): стр. 71-82.

MLADENOVIĆ 2013: MLADENOVIĆ, Radivoje. „Linearizacija predikatskofraznih enklitika u govorima južnog Kosova i južne Metohije“. Južnoslovenski filolog, LXIX (2013): str. 401-415. [orig.] МЛАДЕНОВИЋ, Радивоје. „Линеаризација предикатскофразних енклитика у говорима јужног Косова и јужне Метохије“. Јужнословенски филолог, LXIX (2013): стр. 401-415.

OKUKA 2008: OKUKA, Miloš. Srpski dijalekti. Zagreb: Prosvjeta, 2008.

PAVLOVIĆ 1966: PAVLOVIĆ, Milivoj. „Dijalekatska karakteristika i problemi vranjskog govora“. Vranjski glasnik, II (1966): str. 303-306. [orig.] ПАВЛОВИЋ, Миливој. „Дијалекатска карактеристика и проблеми врањског говора“. Врањски гласник, II (1966): стр. 303-306.

PECO 1989: PECO, Asim. Pregled srpskohrvatskih dijalekata. Beograd: Naučna knjiga, 1989.

PECO 1995: PECO, Asim. „O jednom problemu istorijske fonetike srpskohrvatskog i makedonskog jezika (O sudbini foneme $h \mathrm{u}$ tim južnoslovenskim jezicima)“. Makedonski jazik, XL-XLI (1995): str. 419-427. [orig.] ПЕЦО, Асим. „О једном проблему историјске фонетике српскохрватског и македонског језика (О судбини фонеме х у тим јужнословенским језицима)“. Македонски јазик, XL-XLI (1995): стр. 419-427.

RADIĆ 1997: RADIĆ, Prvoslav. „O govoru Gornje Toplice“. Dani srpskog duhovnog preobraženja, IV (1997): str. 55-68. [orig.] РАДИЋ, Првослав. „О говору Горње Топлице“. Дани српског духовног преображења, IV (1997): стр. $55-68$.

RADIĆ 2000: RADIĆ, Prvoslav. „O jednoj morfološkoj inovaciji u savremenom srpskom jeziku“. Исследования по славянским языкам, V (2000): str. 283290. [orig.] РАДИЋ, Првослав. „О једној морфолошкој иновацији у савременом српском језику“. Исследования по славянским языкам, V (2000): стр. 283-290.

RAJIĆ 1980: RAJIĆ, Ljubiša. „Jezik i identitet - položaj korisnika dijalekta u procesu standardizacije govora“. Godišnjak Saveza društava za primenjenu lingvistiku Jugoslavije, IV-V (1980): str. 373-376.

RAJIĆ 2009: RAJIĆ, Ljubiša. „Gradski govori“. U: Ž. Bošnjaković (ur.), Govor Novog Sada. Sveska 1: Fonetske osobine. Novi Sad: Filozofski fakultet, Odsek 
za srpski jezik i lingvistiku, 2009, str. 31-45. [orig.] РАЈИЋ, Љубиша. „Градски говори“. У: Ж. Бошњаковић (ур.), Говор Новог Сада. Свеска 1: Фонетске особине. Нови Сад: Филозофски факултет, Одсек за српски језик и лингвистику, 2009, стр. 31-45.

SIMIĆ 2011: SIMIĆ, Radoje. „O položaju enklitika u odričnim rečenicama“. Naučni sastanak slavista u Vukove dane, XL/3 (2011): str. 5-13. [orig.] СИМИЋ, Радоје. „О положају енклитика у одричним реченицама“. Научни састанак слависта у Вукове дане, XL/3 (2011): стр. 5-13.

STANKOVIĆ 2017: STANKOVIĆ, Dragana. „Future I in the speech of the Vranje's children in preschool and primary school“. Facta Universitatis, Series: Teaching, learning and teacher education, Vol. 1, No 2 (2017): pp. 113-126.

STANKOVIĆ 2018: STANKOVIĆ, Dragana. „Speech of preschool children and elementary school students from Vranje from the standpoint of urban dialectology“. Facta Universitatis, Series: Teaching, learning and teacher education, Vol. 2, No 1 (2018): pp. 059-070.

STANKOVIĆ 2020: STANKOVIĆ, Dragana. „Upotreba padeža u govoru dece predškolskog i osnovnoškolskog uzrasta iz Vranja - sociolingvistički pristup“. Uzdanica, XVII/2 (2020): str. 49- 64. [orig.] СТАНКОВИТ, Драгана. „Употреба падежа у говору деце предшколског и основношколског узраста из Врања - социолингвистички приступ“. Узданица, XVII/2 (2020): стр. 49- 64.

STANKOVIĆ 1997: STANKOVIĆ, Stanislav. Gradski vlasotinački govor(i) - sociolingvistički procesi (opšte karakteristike). U: M. Pantić (ur.), Dani srpskog duhovnog preobraženja IV. O srpskim narodnim govorima. Despotovac: Narodna biblioteka „Resavska škola“ / Beograd: Interprint, 1997, str. 167-179. [orig.] СТАНКОВИЋ, Станислав. Градски власотиначки говор(и) социолингвистички процеси (опште карактеристике). У: М. Пантић (ур.), Дани српског духовног преображења IV. O српским народним говорима. Деспотовац: Народна библиотека „Ресавска школа“ / Београд: Интерпринт, 1997, стр. 167-179.

STEVANOVIĆ 1969: STEVANOVIĆ, Vladimir. „Govor Poljanice“. Vranjski glasnik, V (1969): str. 399-422. [orig.] СТЕВАНОВИЋ, Владимир. „Говор Пољанице“. Врањски гласник, V (1969): стр. 399-422.

TOMA 1998: ТОМА, Пол Луј. Говори Ниша и околних села. Београд: Институт за српски језик САНУ / Ниш: Просвета, 1998. [orig.] ТОМА, Пол Луј. Говори Ниша и околних села. Београд: Институт за српски језик САНУ / Ниш: Просвета, 1998.

TOMIĆ 2007: TOMIĆ, Dina. „Tragovi balkanskog jezičkog saveza u govoru Ostrovice u Vranjskoj kotlini“. Petničke sveske, LXII (2007): str. 196-203.

TRAJKOVIĆ 2013: TRAJKOVIĆ, Tatjana. „Situaciona upotreba standarda kod nosilaca dijalekta“. Godišnjak za srpski jezik, 26/13 (2013): str. 549-561. [orig.] ТРАЈКОВИЋ, Татјана. „Ситуациона употреба стандарда код носилаца дијалекта“. Годишњак за српски језик, година 26, бр. 13 (2013): стр. 549-561.

TRAJKOVIĆ 2016a: TRAJKOVIĆ, Tatjana. „Govor Preševa“. Srpski dijalektološki 
zbornik, LXIII (2016): str. 284-578. [orig.] ТРАЈКОВИЋ, Татјана. „Говор Прешева“. Српски дијалектолошки зборник, LXIII (2016): стр. 284-578. TRAJKOVIĆ 2016b: TRAJKOVIĆ, Tatjana. „Socio-linguistic research of the dialect of Preševo in the south of Serbia“. Baltistica 51 (2). Vilnus: Universitas Vilnensis, Facultas Philologiae (2016): str. 379-396.

TRAJKOVIĆ 2017: TRAJKOVIĆ, Tatjana. „Niš speech in the light of the newest sociolinguistic research“. Теме - часопис за друштвене науке, XLI (2017): стр. 41-54.

TRAJKOVIĆ 2018a: TRAJKOVIĆ, Tatjana. „Govor Niša kroz prizmu diglosivnosti“. Južnoslovenski filolog, LXXIV/2 (2018): str. 89-108. [orig.] ТРАЈКОВИЋ, Татјана. „Говор Ниша кроз призму диглосивности“. Јужнословенски филолог, LXXIV/2 (2018): стр. 89-108.

TRAJKOVIĆ 2018b: TRAJKOVIĆ, Tatjana. „Govor Preševa u strukturalnoj i varijacionističkoj perspektivi (kao model za dijalektološka predviđanja)“. U: Srpski jezik, književnost, umetnost. Knjiga I: Kurs opšte lingvistike. Kragujevac: Filološko-umetnički fakultet, 2018: str. 173-181. [orig.] ТРАЈКОВИТ, Татјана. „Говор Прешева у структуралној и варијационистичкој перспективи (као модел за дијалектолошка предвиђања)“. Српски језик, књижевност, уметност. Књига I: Курс опште лингвистике. Крагујевац: Филолошко-уметнички факултет, 2018: стр. 173-181

TRAJKOVIĆ, MIHAJLOVIĆ 2020: TRAJKOVIĆ, Tatjana i Milica MIHAJLOVIĆ. „Govor Vranja kroz prizmu diglosivnosti“. Južnoslovenski filolog, LXXVI/1 (2020): str. 77-105. [orig.] ТРАЈКОВИЋ, Татјана и Милица МИХАЈЛОВИЋ. „Говор Врања кроз призму диглосивности“. Јужнословенски филолог, LXXVI/1 (2020): стр. 77-105. 
Dragana Stanković

\section{SOCIOLINGUISTIC APPROACH TO SOME PHONETIC CHARACTERISTICS OF THE SPEECH OF YOUNG PEOPLE FROM VRANJE}

The paper gives the sociolinguistic analysis of some phonetic dialectal features in the speech of yung people from Vranje: semi-sound, consistent ekavism in negative forms of the auxiliary to be in the present tense, loss of the consonant $h$ and reflex ja from final $l$ in past active participle. These language variables are observed in relation to the following social variables, relevant to children's language behavior: age, gender, parental edukation, place of residence, kindergarten / school attendance. The aim of our research to describe certain phonetic characteristics and show their variations under the influence of standard language, and then to determine their representation and conditionality by non-linguistic factors. The analyzed phonetic characteristics show variability and a high degree of exposure to change. The greatest stability is showen by the loss of the consonant $h$, and the least by ekavism nesam, nesi... Based on that, we can talk about the further direction of the development of the phonetic system of Vranje speech. Non-linguistic factors have an influence on the use of the phonetic dialect to some extent, except for age - the use of phonetic dialectisms does not decrease with age.

Keywords: phonetic dialectisms, Vranje speech, youth speech, sociolinguistic approach 